\title{
Measuring consumer knowledge of life insurance products in South Africa
}

\author{
M. Ramchander* \\ Faculty of Management Sciences, Durban University of Technology, ML Sultan Campus \\ P.O. Box 1344, Durban 4000, South Africa \\ *To whom all correspondence should be addressed \\ ManduthR@dut.ac.za
}

\begin{abstract}
The financial services industry is characterized by product suppliers having more information than consumers regarding product features and services. The purpose of this article is to explore this information asymmetry with particular reference to the life insurance industry. Financial advisors, acting as intermediaries, are charged with the task of resolving this asymmetry through mandatory disclosures demanded by regulation. In South Africa, the Financial Services Board (FSB) monitors, regulates and supervises the financial services industry through the Financial Advisory and Intermediary Services Act of 2002 and The Code of Conduct for Financial Advisors. This paper distinguishes financial products from other products and highlights the need for disclosures regarding product features, by financial advisors. Using multistage sampling a national survey was conducted to establish whether consumers are knowledgeable of the features of basic insurance products. The findings were that consumers have a low to very low level of understanding of the features of basic insurance products. The study makes an important contribution to insurers' understanding of consumers' knowledge regarding the features of basic life insurance products. Furthermore, the findings would also contribute to insurers understanding the level to which intermediaries resolve the information asymmetry between product suppliers and consumers.
\end{abstract}

\section{Introduction}

Asymmetric information exists when one party to a transaction is better informed than the other party. Insurers (product suppliers) and intermediaries generally have better information than the consumer regarding financial products and any non-disclosure or poor product description on the part of the intermediary may lead to consumers entering into contracts to their own disadvantage. In exercising their roles intermediaries, financial advisors for example, are supposed to resolve this asymmetry by furnishing product details. Using multistage sampling a national survey was conducted to establish the extent to which consumers can differentiate between the basic features, associated costs and limitations of typical life insurance products, in South Africa.

\section{Objectives of the study}

The objective of the study was to establish the extent to which consumers can differentiate between the basic features, associated costs and limitations of typical life insurance products, in South Africa.

\section{Consumer knowledge}

Knowledge, in general, refers to the information stored in a person's long term memory (Ratchford, 2001). Park, Motherbaugh and Feick (1992) note that some research has operationalised consumer knowledge as consumers' perceptions of what or how much they know while other researchers have operationalized consumer knowledge as the amount and nature of information stored in long term memory. Alba and Hutchinson (2000) claim that consumers are overconfident thinking that they know more than they actually do. Brucks (1985) further categorizes consumer product knowledge into three kinds of knowledge: objective knowledge, subjective knowledge, and prior experience. Subjective knowledge measures an individual's perception of how much she or he knows and objective knowledge measures the amount, type, or organization of what the individual actually has in memory (Ghalandari \& Norouzi, 2012). Philippe and Ngobo (1999) describe product knowledge in terms of declarative class knowledge (product class information) and procedural knowledge (expertise). Park, Motherbaugh and Feick (1994) view product class as information stored in memory, regardless of its truthfulness and can be measured in terms in terms of objective class information and subjective product class information (e.g. consumer perception of his /her product class information). For the purposes of this study product class knowledge is considered for operationalisation of consumer knowledge. The objective class indicators developed include product features, product cost and subjective class information includes perception of knowledge level.

\section{The insurance market}

The insurance market is a vitally important economic institution where mutually beneficial exchanges between consumers and insurance companies take place, wherein consumers purchase the promise of the insurer to cover the financial consequences of a possible loss, paying the insurance premium for this service (Nienaber \& Reinecke, 2009). Information is crucial for this market exchange to take place and it is considered important that consumers can distinguish between the basic features of insurance products. 
There are various types of insurance policies such as Termlife, Whole-life and Disability Insurance. With Term-life Insurance, the contract is so arranged that for the sum assured to be paid on the death of the life assured only in the event of death happening during a specified term, while a Whole-life Insurance contract, on the other hand, provides for the payment of the sum insured on the death of the life insured and may be kept in force for the insured's entire life (Nienaber \& Reinecke, 2009). With Term-life cover, should the insured survive the term there would be no cover beyond the term and upon surrender or expiry, would have no monetary value, as Term-life cover does not incorporate a savings element. With Whole-life cover should the insured terminate the cover, there would be a surrender value depending on the savings.

The cost of life cover is dependent on age and as age progresses the cost of cover increases, being lower for young people and exorbitant for advanced ages. For the same individual the cost of a Term-life policy is far cheaper than Whole-life insurance. For a Term-life policy the premium payment plan may involve a level premium payment plan. With this plan, instead of paying increasing premiums as age progresses through the term, an average premium is paid for the entire term. In other words, the premium remains constant over the term of the policy. The result is that the premiums in the early years are higher than the actual cost of cover and in the latter years the actual cost of cover is higher than the premiums charged. The excess in the earlier years is used to supplement the shortfall in the latter years. A premature termination of a Term-life cover, based on a level premium plan, would be to the detriment of the client, as amounts paid in excess of the actual cost of cover would not be returned to the client.

Disability Insurance is a form of insurance that insures earned income against the risk that a disability prevents the insured to execute the core functions of their work. Botha et al., (2010) note that: "The Code of Good Practice for Disability Insurance includes the principle that avoids accepting cover at levels that would make an individual better off after claiming". The morale hazard would be that, excessive benefits would create an incentive for claiming. In practice, the financial advisor is supposed to request the client to disclose all other disability cover to establish whether the client is not over-insured before selling any new disability cover. If it turns out that the client is over-insured, at the claims stage, the benefit payable would be reduced proportionately so that the monthly benefit payable is not more than $75 \%$ of the monthly income prior to the disability (Botha et al., 2010).

\section{Nature of financial products}

Products and services are frequently divided by economic literature into the categories of search goods, experience goods and credence goods (Wan, Nakayama, \& Sutcliffe, 2012). In order to make a purchasing decision, necessary knowledge needs to be gathered, which may accrue costs that vary according to the category of the product or service, being somewhat lower for search goods and significantly higher for credence goods (Pacces, 2000). Search goods include items such as clothing, equipment and furniture, the value and quality of which can be ascertained in advance and there may be guarantees or warranties attached allowing for the rectification of any future faults. On the other hand, the utility impact of credence goods is difficult to measure after consumption as well.

The opportunity for learning from prior experience, with financial products, is very limited as such products are not purchased on a regular basis and the consumer's ability to also learn from the experience of others is also limited, as matters concerning financial products are considered to be very personal. With financial products, the value or quality is difficult to establish before and even after the purchase as feedback is not immediate (Pacces, 2000). The reality is that an extended period of time needs to elapse before one becomes aware of the true value of a financial product or for that matter any shortcomings. Hence a situation results where product suppliers having better information than consumers leading to a situation of asymmetric information. The Insurance market therefore requires intermediaries, financial advisors for example, to resolve the situation of asymmetric information.

\section{Asymmetric information and intermediaries}

Asymmetric information may cause the less informed market participants to conclude contracts to their own detriment (Kalss, 2007). With regards to the provision of financial services, Malherbe and Morojele (2001) reported that asymmetric information can be so extreme that the client knows virtually nothing of the product being offered, the nature of the organization offering it and the intermediary advising the client to buy it.

Allen and Santomero (1999:4) describe the role of intermediaries to be "the rendering of services to clients to bridge the gap between clients' lack of knowledge and the expertise required to get the most out of increasingly sophisticated financial markets". More commonly the term "agent" is used to denote someone who acts as a middleman on behalf of someone else. In an insurance context such agents are financial advisors or insurance brokers. The Financial Advisory and Intermediary Services (FAIS) Act of 2002 provides the regulatory framework that guides the conduct of financial advisors in South Africa (RSA, 2002).

\section{Financial regulation}

McVea (2005) notes firstly, that the market may be unable to supply a socially optimal level of information for investors and secondly, there may be factors which prevent individuals from appreciating this information. The objective of the Financial Advisory and Intermediary Services Act (2002) is to regulate the rendering of advice and intermediary services to clients. Section 7(1) of the General Code of Conduct requires the financial service provider to provide a reasonable and appropriate explanation of the nature and material terms 
of the relevant contract with a client, and generally make a full and frank disclosure of any information that would reasonably expect a client to make an informed decision (RSA, 2003). This challenge was highlighted by Swanepoel (2006) pointing out that product suppliers historically simplified their quotations and marketing material by excluding specific terms and conditions resulting in abbreviated documents containing key features of the product and only send clients relevant and material information, that needs to be disclosed before concluding a transaction, some weeks after the transaction has been concluded. Abbreviated documents and marketing material, that exclude specific terms and product features limits the extent to which full product disclosure can be made.

Botha et al. (2010) describe compliance as conforming to the meeting of requirements of laws and regulations that have been clearly defined and relevant to the financial services industry. Section 17(1) of the FAIS Act (RSA, 2002) makes it compulsory for financial service providers, to appoint (internally or outsource) a compliance officer to establish and maintain procedures to be followed by the representative in order to ensure compliance. Any 'tickbox' approach to compliance that includes ticking against statements that relate to product description or fees having been disclosed would do little to improve the actual levels of disclosure.

\section{Sampling, sampling techniques and description of the sample}

Reported here is the methodology underlying the study designed to establish the extent to which consumers can differentiate between the basic features of life insurance products, in South Africa. A cross-sectional survey study was considered to be appropriate.

The Living Standards Measure (LSM) was developed by the South African Advertising Research Foundation (SAARF) whereby households were classified into ten groups according to amenities at the disposal of the household and the area where they live, with LSM 1 denoting households with the lowest and LSM 10 the highest living standards (Martins, 2006). The Bureau of Market Research estimated that for households falling in the LSM 1 group, food, clothing and footwear, and housing contributed to almost $80 \%$ of the cash budget of households with food alone consuming $71 \%$ of the budget with this decreasing to $24 \%$ for the LSM 6 group and less than $11 \%$ for the LSM 10 group (Martins, 2006).

According to FinMark Trust (2010), 23\% (7.8 million) of South African adults have some life insurance products covering a defined risk, with $19 \%$ (6.3 million) having life coverage, comprising 2\% of LSM 1-4 population, $12 \%$ of LSM 5-6 population, $35 \%$ of the LSM 7-8 population and $56 \%$ of the LSM 9-10 population.
In South Arica, the largest province by population is KwaZulu-Natal followed by Gauteng, Eastern Cape, Western Cape, Limpopo, North West, Mpumalanga, Free State and Northern Cape in order of decreasing population sizes. More than $75 \%$ of the population is represented in five of the largest provinces. Using these five provinces resulted in 10 permutations of sets of three provinces. From these permutations one set was selected at random. The set of provinces selected was KwaZulu-Natal, Gauteng and Western Cape.

Given the profile of the population ( $35 \%$ and $56 \%$ of the LSM 7-8 and LSM 9-10 categories, respectively), it was considered very likely that members of the population would have relatively more disposable income than members of other LSM categories. It was also assumed that much of this disposable income would be spent at retail outlets. Prinsloo (2010) adjusted the hierarchical model of shopping centres in South Africa, developed by Kahn (1988) for a better understanding of the retail market, by incorporating threshold values of specific LSM groups that are required to warrant retail of any kind. Consumers at super regional centres and major regional centres share the same LSM characteristics, according to Prinsloo's model, as the population.

For each of the selected provinces, a sampling frame was constructed, using the Mall Guide Database (2011) containing all the super-regional and major regional centers in each province. From each list a retail centre was selected randomly. A mall in Randburg, Kennilworth and Westville was selected in the province of Gauteng, Western Cape and KwaZulu Natal respectively.

The mall intercept survey is used most frequently for market research and generally entails selecting respondents by stopping them (i.e. intercepting them) in a public place (e.g. a shopping mall) and once a potential respondent is stopped by an interviewer, he or she can be screened using criteria that determine whether an individual would qualify as a subject (Butler, 2008). A questionnaire with two sections was constructed, comprising close-ended questions, constituting structured statements or assertions. The purpose was to elicit perceptions held by respondents regarding various variables of interest. The sample consisted of 369 respondents that were heterogeneous with regards to education level and age grouping.

\section{Results and data analysis}

\section{Demographic details}

The distributions according to demographic details are illustrated in Table 1. 
Table 1: Distribution according to demographic details

\begin{tabular}{|c|c|c|c|c|}
\hline Variable & & Percen-tage & Number & Total \\
\hline Gender & $\begin{array}{l}\text { Male } \\
\text { Female }\end{array}$ & $\begin{array}{l}51 \% \\
49 \%\end{array}$ & $\begin{array}{r}190 \\
179\end{array}$ & 369 \\
\hline Race & $\begin{array}{l}\text { Black } \\
\text { Coloured } \\
\text { Indian } \\
\text { White } \\
\end{array}$ & $\begin{array}{c}57 \% \\
13 \% \\
8 \% \\
22 \% \\
\end{array}$ & $\begin{array}{c}209 \\
48 \\
29 \\
83\end{array}$ & 369 \\
\hline Age-group & $\begin{array}{l}26-35 \\
36-45 \\
46-55 \\
56-65 \\
65+ \\
\end{array}$ & $\begin{array}{l}38 \% \\
23 \% \\
20 \% \\
11 \% \\
8 \% \\
\end{array}$ & $\begin{array}{c}140 \\
85 \\
75 \\
39 \\
30 \\
\end{array}$ & 369 \\
\hline Place & $\begin{array}{l}\text { Gauteng } \\
\text { Western cape } \\
\text { Kwazulu natal }\end{array}$ & $\begin{array}{l}35 \% \\
27 \% \\
38 \%\end{array}$ & $\begin{array}{c}129 \\
98 \\
\\
142\end{array}$ & 369 \\
\hline $\begin{array}{l}\text { Highest educational } \\
\text { Qualification }\end{array}$ & $\begin{array}{l}\text { Grade } 11 \text { or lower } \\
\text { Grade } 12 \\
\text { Post matric dip/cert } \\
\text { Bdegree } \\
\text { Post grad. Degree }\end{array}$ & $\begin{array}{c}6 \% \\
35 \% \\
37 \% \\
\\
13 \% \\
8 \%\end{array}$ & $\begin{array}{c}23 \\
\\
130 \\
139 \\
\\
48 \\
29\end{array}$ & 369 \\
\hline
\end{tabular}

\section{Responses to knowledge of basic features of insurance products}

The responses to statements regarding knowledge of the basic features of insurance products are illustrated in Table 2.

Table 2: Responses to knowledge of features of basic insurance products

\begin{tabular}{|c|c|c|c|c|c|c|}
\hline & \multirow[t]{2}{*}{ Statements } & \multicolumn{2}{|l|}{ Agree } & \multirow{2}{*}{$\begin{array}{r}\text { Disagree } \\
\mathrm{N}\end{array}$} & \multicolumn{2}{|l|}{ Total } \\
\hline & & $\mathrm{N}$ & $\%$ & & $\%$ & $\mathrm{~N}$ \\
\hline 2.1 & $\begin{array}{l}\text { I experience difficulty in telling the difference between the } \\
\text { different Life insurance products }\end{array}$ & 254 & 69 & 115 & 31 & 369 \\
\hline 2.2 & $\begin{array}{l}\text { A Term-life cover provides death cover until the day the } \\
\text { insured dies }\end{array}$ & 267 & 72 & 102 & 28 & 369 \\
\hline 2.3 & $\begin{array}{l}\text { I consider my knowledge of basic Life insurance products to } \\
\text { be good (above average) }\end{array}$ & 168 & 45 & 201 & 55 & 369 \\
\hline 2.4 & A Term-life cover expires (ends) after a specified period & 122 & 33 & 247 & 67 & 369 \\
\hline 2.5 & A Term-life cover can include a savings element & 253 & 69 & 116 & 31 & 369 \\
\hline 2.6 & $\begin{array}{l}\text { For the same premium the insured would be able to buy Term- } \\
\text { life cover of a far greater value than Whole-life cover }\end{array}$ & 159 & 43 & 210 & 60 & 369 \\
\hline 2.7 & A Term-life cover cannot be used as a means to save & 131 & 35 & 238 & 65 & 369 \\
\hline 2.8 & $\begin{array}{l}\text { For the same amount of death cover the premiums for a Term- } \\
\text { life cover will be far less than that for a Whole-life cover }\end{array}$ & 125 & 34 & 244 & 66 & 369 \\
\hline 2.9 & $\begin{array}{l}\text { There is no maximum limit to the amount of disability that I } \\
\text { can buy }\end{array}$ & 220 & 60 & 149 & 40 & 369 \\
\hline 2.10 & $\begin{array}{l}\text { The maximum disability cover that I can buy is regulated by } \\
\text { law }\end{array}$ & 133 & 36 & 236 & 64 & 369 \\
\hline
\end{tabular}

Just over two thirds (69\%) of the respondents agreed that they experience difficulty in telling the difference between the different life insurance products. Furthermore, only $45 \%$ of the respondents considered that their knowledge of basic life insurance products to be good (above average). If the claim made by Alba and Hutchinson (2000) that consumers are overconfident, thinking that they know more than they actually do, is taken into consideration, then this result should 
in reality be actually lower. These responses serve as an indicator that the level of knowledge regarding basic life insurance products was rather limited.

With Term-life Insurance the contract is so arranged that for the sum assured to be paid on the death of the life assured only in the event of death happening during a specified term. However, $72 \%$ of the respondents think that a Term-life cover provides cover until the day the person dies. This incorrect understanding is further reinforced by close to the same proportion $(67 \%)$ of the respondents disagreeing that a Termlife cover expires after a specified date. Further misunderstandings of the features of term life cover are illustrated by respondents $(69 \%)$ believing that a Term-life cover can include a savings element. This incorrect understanding is further reinforced by only $35 \%$ of the respondents agreeing that a Term-life cover cannot be used as a means to save.

These findings are significant in the sense that respondents have false expectations regarding the benefits of Term-life insurance and upon the expiry of a term the respondents may:

(i) find themselves without cover or having no option but to initiate new cover at much higher premiums due to advancement in age at the point in time; and/or

(ii) anticipate some cash value when there is really none.

For the same individual, Term-life cover is significantly cheaper than Whole-life cover. However, responses indicate that respondents do not understand the impact on the premiums paid depending whether Term-life cover or Wholelife cover is elected. In the first response $60 \%$ of the respondents disagreed with the statement that for the same premium the insured would be able to buy Term-life cover of far greater value that Whole-life cover. This incorrect understanding was further reinforced by $66 \%$ disagreeing that for the same amount of death cover the premiums for a Termlife cover will be far less than that for a Whole-life cover.

These findings are significant as consumers may for the same financial outlay:

(i) select Term-life cover when Whole-life cover is really needed;

(ii) cancel an existing Whole-life cover and substitute a Term-life cover believing that they are getting better value for money; and

(iii) compare the amount of Term-life cover offered by one product supplier to the amount of Whole-life cover offered by another product supplier and decide that there is greater value for money in the one as compared to the other.

Finally, $60 \%$ of the respondents agree with the statement that there is no maximum limit to the amount of disability cover that can be bought, which is an incorrect statement.
Furthermore, with $64 \%$ disagreeing with the correct statement that the maximum disability cover is regulated by law, it may come as a surprise in the unfortunate case of disability, that benefits would be reduced proportionately.

\section{Knowledge score}

A knowledge score was computed depending on the correctness of the answers provided to the questions relating to the features of basic insurance products. The minimum score possible was zero and the maximum possible score was 10. The mean score was 3.74 with a standard deviation of 1.94. The results are illustrated in Figure 1.

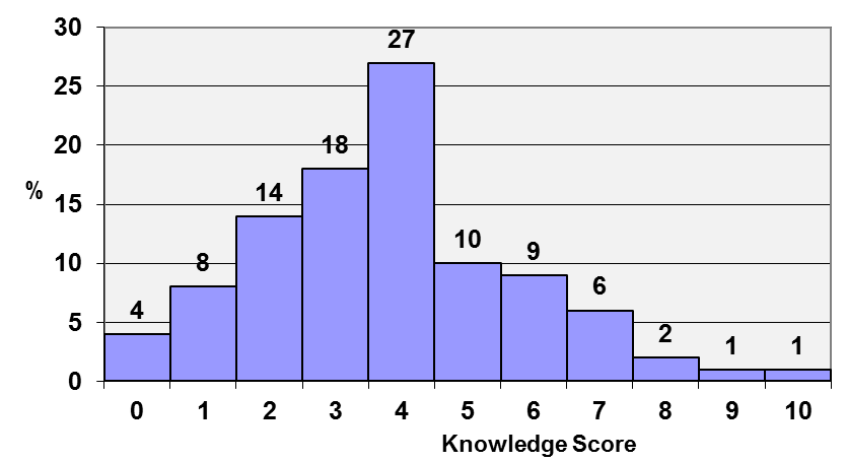

\section{Figure 1: Knowledge score}

The distribution of the knowledge score was positively skewed (skewness value of 0.353). The KolmogorovSmirnov test compares the score in a sample to a normally distributed set of scores with the same mean and standard deviation (Field, 2010). According to Field (2010), if the test is significant $(\mathrm{p}<0.05)$, the distribution is significantly different from a normal distribution (not normal). The Kolmogorov-Smirnov test was highly significant $[\mathrm{D}(369)=0.162, \mathrm{p}<0.001]$. It was concluded that the distribution was not normal. To use the normal approximation continuity corrections were applied.

\section{Reliability of knowledge score}

The test on Knowledge included 10 questions. However, there were only five key questions, each asked in two different ways. Question 2.1 relates to question 2.3, question 2.2 relates to question 2.4 , and so on. The sets of questions were cross-tabulated to establish whether respondents answered the related questions in the same way. The responses are cross-tabulated in Table 4. Yate's continuity correction prevents the overestimation of statistical significance, by adjusting Pearson's chi-square in discrete distributions (Devore, 1995). Even though a chi-square test may show a statistical significance between two variables, the relationship between those variables may not be substantially important. Pearson's contingency coefficient is therefore used to measure the relative strength of an association between two variables (Field, 2010). 
Table 3: Cross-tabulation matrix for responses to knowledge questions

\begin{tabular}{|c|c|c|c|c|c|}
\hline \multirow[b]{2}{*}{$\mathrm{N}=369$} & \multicolumn{3}{|c|}{ Continuity correction } & \multicolumn{2}{|c|}{ Contingency coefficient } \\
\hline & Value & df & Asym.Sig & Value & Approx.Sig \\
\hline $\begin{array}{l}\text { Term-life provides death cover until the day the person dies/ Term- } \\
\text { life cover expires after a specified period }\end{array}$ & 87.31 & 1 & $.004 *$ & $.550 * *$ & .005 \\
\hline $\begin{array}{l}\text { A Term Life cover can include a savings component/ A Term-life } \\
\text { cover cannot be used as a means to save }\end{array}$ & 122.9 & 1 & $.000 *$ & $.504 * *$ & .000 \\
\hline $\begin{array}{l}\text { For the same premium the insured would be able to buy Term cover } \\
\text { of a far greater value than Whole-life cover/ For the same amount } \\
\text { of death cover the premiums for a Term-life will be far less than that } \\
\text { for a Whole-life cover }\end{array}$ & 219.1 & 1 & $.000 *$ & $.613 * *$ & .000 \\
\hline $\begin{array}{l}\text { There is no limit to the amount of disability cover that I can buy/ } \\
\text { The maximum disability cover that I can buy is regulated by law. }\end{array}$ & 146.6 & 1 & $.000 *$ & $.537 * *$ & .000 \\
\hline
\end{tabular}

* There were significant relationships $(\mathrm{p}<.05)$ between cross-tabulated items.

** The strength of the relationships was high $(>0.5)$.

It can be inferred that respondents seem to have understood the questions and answered them consistently.

\section{Knowledge score according to demographics}

Table 4 presents the Knowledge Score according to gender.
Table 4: Knowledge score according to gender

\begin{tabular}{ll|r|r|r|r}
\hline & Gender & & N & $\begin{array}{c}\text { Std. } \\
\text { Deviation }\end{array}$ & $\begin{array}{c}\text { Std. } \\
\text { Error } \\
\text { Mean }\end{array}$ \\
\hline Score for & Female & 190 & 3.92 & 2.062 & .150 \\
Section B & Male & 179 & 3.55 & 1.787 & .134 \\
\hline
\end{tabular}

The mean score for males was 3.92 and that for females was 3.55. This difference was explored further through the Independent Samples Test illustrated in Table 5.

Table 5: Independent samples test for gender

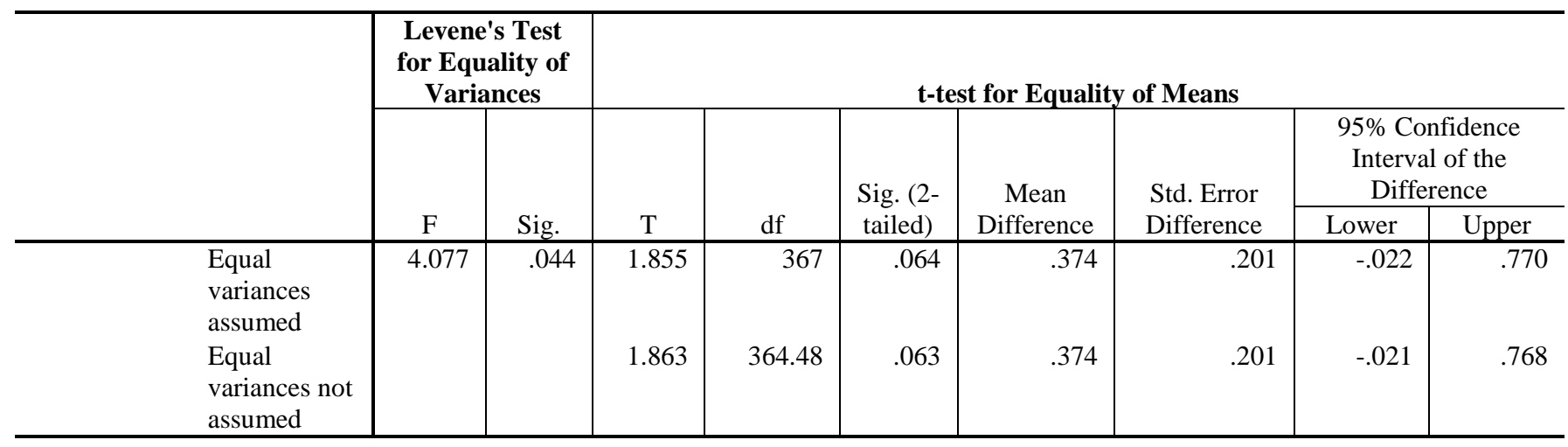

According to Field (2010), Levene's test, tests the null hypothesis that the variances in different groups are equal and concludes that the assumption of equal variance is tenable at $p>0.05$. The assumption of homogeneity of variances would be violated at $\mathrm{p}<0.5$. While Levene's test $[\mathrm{F}(1.367)=4.077$, $\mathrm{p}<0.05]$ indicated that the variances between the knowledge scores for males and females were significantly different, the $\mathrm{t}$-Test $[\mathrm{t}(364.48)=1.863, \mathrm{p}>0.05]$ for gender (equal variance not assumed) indicated that there was no evidence to suggest that males and females performed differently with respect to knowledge scores.
According to Girden (1992), Analysis of variation (ANOVA) is a statistical test used to determine if more than two population means are equal, by using the F-distribution function and information about the variances of each population and groupings of populations to establish whether variability between and within each population are significantly different. Table 6 presents the ANOVA according to race, age group, place and level of educational qualification. 
Table 6: Anova according to race, age group, place and level of educational qualification

\begin{tabular}{l|l|l|l|l|l|l|l}
\hline & Homogeneity of variance & \multicolumn{3}{l}{ ANOVA } & Sig \\
& $\begin{array}{l}\text { Levene } \\
\text { Statistic }\end{array}$ & df1 & df2 & Sig & df & F & \\
\hline RACE & 1.383 & 3 & 365 & 0.254 & 3 & 0.156 & 0.926 \\
\hline AGE GROUP & 0.238 & 4 & 364 & 0.917 & 4 & 2.039 & 0.088 \\
\hline PLACE & 19.345 & 2 & 366 & 0.000 & 2 & 1.041 & 0.354 \\
\hline $\begin{array}{l}\text { LEVEL OF EDUCATIONAL } \\
\text { QUALIFICATION }\end{array}$ & 2.884 & 4 & 364 & 0.023 & 4 & 0.763 & 0.550 \\
\hline
\end{tabular}

The ANOVA that were performed by race $[\mathrm{F}(3.365)=0.155$, $\mathrm{p}>0.5]$, age group $[\mathrm{F}(4.464)=2.039, \mathrm{p}>0.05]$, place $[\mathrm{F}(2.366)=1.041, \mathrm{p}>0.05]$, and level of educational qualification $[\mathrm{F}(4.364)=0.763, \mathrm{p}>0.05]$ does not present any evidence to suggest that respondents performed differently on the knowledge score, due to race, age, place and level of education.

The Knowledge scores were then grouped into four categories (very low, low, high, very high) as illustrated in Table 7.

Table 7: Knowledge score according to categories

\begin{tabular}{l|l|l|l}
\hline $\begin{array}{l}\text { Knowledge } \\
\text { Score } \\
\text { Category }\end{array}$ & Frequency & Percentage & $\begin{array}{l}\text { Cumulative } \\
\text { Percent }\end{array}$ \\
\hline Very low & 96 & 26.0 & 26.0 \\
\hline Low & 168 & 45.5 & 71.5 \\
\hline High & 94 & 25.5 & 97.0 \\
\hline Very high & 11 & 3.0 & 100 \\
\hline & 369 & 100.0 & \\
\hline
\end{tabular}

It was found that $71.5 \%$ of the respondents scored either at the low or very low level of understanding of the features of basic insurance products.

Consumers of insurance products have a low to very low level of understanding of the features of basic insurance products, and this knowledge is not a function of gender, race, age, place or level of education. For example, any inference such as an individual holding a postgraduate qualification would be in a better position to make an informed purchasing decision, regarding a Life insurance product, would be totally unfounded and contrary to the findings.

\section{Possible implication for management in the insurance industry}

The low to very low product knowledge score indicate that respondents have entered into life insurance contracts with a somewhat limited understanding of product features. A further implication is that the asymmetric information between product suppliers and consumers has not been satisfactorily resolved by the intermediary, who is the financial advisor in this case. Abbreviated documents and marketing material, that exclude specific terms and product features limits the extent to which full product disclosure can be made. It is incumbent upon product suppliers to put financial service providers in the position to do. This calls for more elaborate product description documents, the explanation of which may have the effect of extending the duration of the meeting between the client and the financial advisor.

\section{Conclusion and recommendations}

Asymmetric information between clients and product suppliers in the insurance industry is the result of the unique features of financial products and services. Financial service providers through financial advisors are supposed to resolve this asymmetry through advice. The advice that is provided is regulated through the FAIS Act and the Code of Good Conduct for Financial Advisors. The regulation demands that features of the products being sold are clearly explained to the client.

However, in practice clients seem to have a low or very low level of understanding of the features of basic insurance products. This low to very low level of knowledge does not correlate with race, age, place of educational qualification. It would appear that the asymmetry regarding knowledge of basic insurance products remains unresolved.

It is recommended that:

- Product suppliers, prepare a generic product description differentiation matrix that is made available for the clients' attention, through the financial advisor. A quick glance through the document should furnish the necessary information that distinguishes the basic features of life insurance products. A simple example is provided for illustration purposes in Table 9

- A copy of the product differentiation matrix should bear the signature of the client across the recommended product and be retained amongst the necessary documents in the client's file.

- Product suppliers follow up with their clients whether they are satisfied with the product after the client is in position of the policy documents. 
Table 8: features of basic insurance products

\begin{tabular}{|c|c|c|c|}
\hline Product & $\begin{array}{l}\text { Product A: } \\
\text { Term Life } \\
\text { cover }\end{array}$ & $\begin{array}{l}\text { Product B : } \\
\text { Whole life } \\
\text { cover }\end{array}$ & $\begin{array}{l}\text { Product C: } \\
\text { Universal } \\
\text { life cover }\end{array}$ \\
\hline $\begin{array}{l}\text { What is the } \\
\text { duration of } \\
\text { cover? }\end{array}$ & $\begin{array}{l}\text { Fixed } \\
\text { period: eg } \\
20 \text { years } \\
\text { No cover } \\
\text { after term } \\
\text { expires }\end{array}$ & Entire life & Entire life \\
\hline $\begin{array}{l}\text { Is savings } \\
\text { incorporated? }\end{array}$ & No & Yes & Yes \\
\hline $\begin{array}{l}\text { Is there a } \\
\text { surrender } \\
\text { value? }\end{array}$ & No & $\begin{array}{l}\text { Yes, value } \\
\text { depends on } \\
\text { savings }\end{array}$ & $\begin{array}{l}\text { Yes, value } \\
\text { depends on } \\
\text { savings }\end{array}$ \\
\hline $\begin{array}{l}\text { Can the } \\
\text { amount of } \\
\text { cover be } \\
\text { adjusted? }\end{array}$ & No & No & Yes \\
\hline $\begin{array}{l}\text { Can the } \\
\text { premiums be } \\
\text { adjusted? }\end{array}$ & No & No & Yes \\
\hline Relative Cost & $\begin{array}{l}\text { Less } \\
\text { expensive }\end{array}$ & Expensive & $\begin{array}{l}\text { Most } \\
\text { Expensive }\end{array}$ \\
\hline
\end{tabular}

\section{References}

Alba, J. \& Hutchinson, J.W. 2000. 'Knowledge calibration: What consumers know and what they think they know', Journal of Consumer Research, 27: 123-156.

Allen, F. \& Santomero, A.M. 1999. What do financial intermediaries do?, Wharton School W.P. University of Pennesylvania.

Botha, M., Rossini, I., Geach, W., Goodall, B. \& du Preez, L. 2010. The South African planning handbook 2010, LexisNexis, Durban.

Brucks, M. 1985. 'The effects of product class knowledge on information search behavior', Journal of Consumer Research, 12: 116.

Butler, S. 2008. Mall intercept survey, encyclopedia of survey research methods, Sage, Thousand Oaks.

Devore, J.L. 1995. Probability and statistics for engineering and the sciences, $4^{\text {th }}$ Ed, Duxbury Press.

Field, A. 2010. Discovering statistics using SPSS, $3^{\text {rd }}$ Ed. London, Sage.

FinMark Trust. 2010. Consumer Survey in South Africa, FinScope, Pretoria.

FSB (Financial Services Board). 2009. Annual report, Pretoria, FSB.

Ghalandari, K. \& Norouzi, A. 2012. 'The effect of country origin on purchase intention: The role of product knowledge', Research Journal of Applied Sciences, Engineering and Technology, 4(9): 1166-1171.

Girden, E.R. 1992. ANOVA: Repeated measures, Sage University paper series on quantitative applications in the social sciences, Newbury Park, Sage.
Kahn, M. 1988. Change and evolution of shopping centres, Paper delivered at 1988 Conference of the Institute of Town and Regional Planners, Sun City, October.

Kalss, S. 2007. 'Recent developments in liability for nondisclosure of capital market information', International Review of Law and Economics, 27: 70-95.

Malherbe,S. \& Morojele, M. 2001. The cost and benefits of the financial advisory and intermediary services bill, http://www.pmg.org.za, [accessed 21 May 2011].

Mall Guide Database. 2011. Show all listed malls, http://www.mallguide.co.za [Accessed 3 January 2011].

Martins, J.H. 2006. 'Household cash expenditure by living standards measure group', Journal of Family Ecology and Consumer Sciences, 34: 1-9.

McVea, H. 2005. 'Financial services regulation under the financial services authority: A reassertion of the market failure thesis?', Cambridge law Journal, 64(2): 413-448.

Nienaber P.M. \& Reinecke M.F.B. 2009. Life insurance in South Africa: A compendium, LexisNexis, Durban, South Africa.

Pacces, A.M. 2000. 'Financial intermediation in the securities markets: Law and economics of business regulation', International Review of Law and Economics, 20(1): 479-510.

Park, C.W, Motherbaugh D.L. \& Feick, L. 1992. 'Consumer knowledge assessment: How product experience and knowledge of brands, attributes and features affects what we think we know, Advances in Consumer Research, 19: 193-198.

Park, C.W., Motherbaugh D.L. \& Feick, L. 1994. 'Consumer knowledge assessment', Journal of Consumer Research, 21: 71- 82.

Philippe, A. \& Ngobo, P. 1999. 'Assessment of consumer knowledge and its consequences: A multi-component approach', Advances in Consumer Research, 26: 569-575.

Prinsloo, D.A. 2010. 'Classification and hierarchy of retail facilities in South Africa', Urban Studies, September.

Ratchford, B.T. 2001. 'The economics of consumer knowledge', Journal of Consumer Research, 27(4): 397-411.

RSA. 2002. The financial advisory and intermediary services Act of 2002 (Gazette No: 24079), Pretoria, Government Printer.

RSA. 2003. General code of conduct for authorized financial service providers and representative (Gazette No. 25299), Pretoria: Government Printer.

Swanepoel, A. 2005. 'The record of advice serves as vital evidence', FSB Bulletin, Third Quarter: 22.

Swanepoel, A. 2006. 'Financial service provider's plea to product supplier’, FSB Bulletin, 12(2):18.

Wan, Y., Nakayama, M. \& Sutcliffe, N. 2012. 'The impact of age and shopping experiences on the classification of search, experience, and credence goods in online shopping', Information Systems and $e$ Business Management, 10(1):135-148. 